\title{
FESTIVAL FEVER AND INTERNATIONAL DJs: The Changing Shape of DJ Culture in Sydney's Commercial Electronic Dance Music Scene

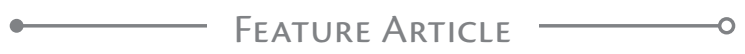

\author{
ED MONTANO \\ RMIT UNIVERSITY
}

\begin{abstract}
In recent years there has been an increase in the number of electronic dance music festivals in Sydney. This has served to shift the clubbing landscape in the city from night to daytime, taking dance music out of clubs and into parks and other public spaces. With its roots in imported versions and local interpretations of overseas dance culture, the dance scene in the city has always been heavily dependent on international sounds and fashions. With the dominance of these festivals, such as Field Day, Parklife, Harbourlife, Future Music, Creamfields, Good Vibrations and Stereosonic, this dependence is further emphasised through the high billing of international DJs in promotional material. Drawing on a decade of ethnographic research and participant-observation in the commercial electronic dance music scene in Sydney, this article explores how this festival fever is changing the shape of DJ and dance music culture in the city.
\end{abstract}

KEYWORDS: Sydney, DJs, club culture, festivals, mainstream, underground

Ed Montano is a lecturer in Music Industry at RMIT University. He has an MA in Popular Music Studies from the Institute of Popular Music at the University of Liverpool and a $\mathrm{PhD}$ on the commercial Sydney dance music scene from Macquarie University. 


\section{INTRODUCTION}

DURING THE PAST DECADE, the commercial Sydney electronic dance music $\left(\mathrm{EDM}^{1}\right)$ scene has become dominated by annual festivals. The early 2000s saw the rise in popularity of a select few events such as Field Day and Parklife, alongside which the regular club scene continued to prosper. In recent years, however, there has been a marked increase in the number of festivals taking place throughout the year, and this has seemingly had a detrimental effect on the popularity of regular club nights, with the suggestion that there is now an over-saturation of festivals. Extensive discussion within the scene and the local EDM media currently circulates around this topic, framing this explosion of festivals in both positive and negative perspectives. ${ }^{2}$ It is clearly an issue of concern for the scene's participants (DJs, promoters, clubbers), and in the way it is changing the shape and constitution of the city's club culture, it warrants further consideration. The research and fieldwork that underpins this article has been conducted over the past ten years and is ongoing. I draw on interviews I have conducted with DJs, promoters and other industry personnel during this time, as well as a variety of local media sources such as street-press and websites and my work in dance music retail. During this research, I have witnessed the increasing dominance of festivals, several of which I have attended, and so my observations are partially based in personal participation.

One recurring motif in the discussion that surrounds the scene that has continually caught my attention centres on the concepts of the "underground" and the "mainstream". It is this motif that I wish to use in this article as a way of framing my consideration of the impact of EDM festivals in Sydney. I would suggest that the development of these festivals makes evident the way EDM is now firmly located within the mainstream and that the people responsible for staging these festivals have made a deliberate attempt to draw mainstream audiences into what, at least initially, was an underground phenomenon. The artist line-ups for these festivals also bring into play these divisions, in the way they fuse the obscure with the well-known, presenting underground music to mainstream crowds and mainstream sounds to underground audiences. In doing so, it seems that the barriers that previously existed between underground scenes and mainstream audiences are collapsing.

Any consideration of the notions of underground and mainstream within a contemporary EDM context needs to be supported with an awareness of the historical relevance of the terms. The music has a history that dates back to the late 1960s and the initial stirrings of disco in the African-American and gay communities of New York. This history has been traced by a number of writers, most thoroughly by Brewster and Broughton in their comprehensive history of the DJ (2000), by Poschardt in his exhaustive work on DJ culture (1998), and by Fikentscher in his detailed exploration of post-disco underground dance music in New York (2000). Similarly, the UK's engagement with underground dance culture has been discussed by Collin in his work on ecstasy culture and acid house (1998), by Haslam in his history of British DJ culture (2001), and by Phillips in his account of dance music in the 1990s with the rise of superstar DJs and superclubs (2009). Bidder's text merges 
the two countries, working its way through both American and British developments in dance music and club culture (2001; written as an accompaniment to the British three-part television series Pump Up The Volume [Hindmarch 2001]), as does Reynolds' history of house, techno and rave (1999). Below is a summary of this historical progression of dance music, which is intended to map the development of dance music from underground to mainstream phenomenon, as a way of providing a contextual background for my analysis of the scene in Sydney. It is my argument that the festivals that now dominate the city's EDM culture represent the apotheosis of dance music's filtering into the mainstream.

\section{Disco}

Prior to beCOMING COMMERCIALISED at the hands of a music industry seeking to make a quick profit, disco referred to a diverse culture and music grounded in the concepts of dancing, partying and escapism. By the end of the 1970s, the term had become shorthand for a glossy, rhythmic style of music, with a solid four/four beat, layers of sweeping strings and dramatic vocals, with wider socio-cultural associations of fame, glamour, hedonism, celebrity and exclusivity (Fikentscher 2000: 22). All of this contradicted what disco had initially been about, in its fusion of a variety of music styles and its ideals of unity and inclusion. In the charged social and cultural context of a post-civil rights America and a post-Stonewall riots New York, disco brought together the gay and African-American undergrounds around a sense of freedom and liberation. While disco may now be indelibly linked to the music of the Village People, the Bee Gees and the Saturday Night Fever soundtrack, and glitzy venues like the infamous Studio 54 (Poschardt 1998), in its original incarnation it was about music that was "funky and soulful", within a scene that was "small, gritty and underground" (Brewster and Broughton 2000: 138).

The underground disco scene in New York also gave rise to the now-familiar figure of the dance music DJ. Pioneers such as Francis Grasso, David Mancuso and Nicky Siano turned DJing into a creative practice and carved out loyal underground followings at their respective clubs (the Sanctuary, the Loft, the Gallery), laying the foundations for the contemporary DJ and the modern club scene. They made the DJ the central focus of the dance club and someone who could shape the emotional mood of the dancer through a particular selection and sequencing of music. The idea of mixing this music into a continuous flow developed through the work of Grasso, and remains to this day one of the founding principles of DJing (albeit to widely varying degrees, depending on the dance music sub-genre the DJ operates within).

As this underground music and culture gathered momentum and popularity, disco began its brief flirtation with the mainstream (Gilbert and Pearson 1999: 9). The pioneering work of DJs and producers such as Walter Gibbons and Tom Moulton, and their embracing of the concept of the remix and the 12-inch format, set the musical parameters for contemporary dance music production. Independent record labels like Philadelphia International and Salsoul released many of the records that would come to epitomise the disco sound. Yet this 
was a sound that became commercialised by the major labels. As with many of the other fads and phases that have characterised the development of popular music, disco's time in the mainstream was relatively brief.

\section{HOUSE MUSIC IN THE UNDERGROUND}

SUCCUMBING to the exploitative tendencies of the music industry's major labels, disco as a mainstream phenomenon collapsed almost as quickly as it had appeared. In subsequent years, the use of the term disco had certain disparaging and negative aspects, resulting in the re-framing of the styles that flowered from disco as "dance music". With its roots in the African-American and gay communities, there were undercurrents of racism and homophobia behind disco's dismissal, exemplified by American radio DJ Steve Dahl's "Disco Sucks" campaign (Fikentscher 2000: 11). Yet while the mainstream may have been quick to dismiss disco as a passing fad, DJs and clubbers continued to explore dance music, hidden away again in the underground. With the development of new technologies such as drum machines and synthesisers, producers in Chicago and Detroit took dance music in completely new directions, inventing house and techno in the process (Gilbert and Pearson 1999: 73-6). Taking inspiration from the rhythms of disco and the energies of the dance floor, as well as from their surrounding urban environment, Frankie Knuckles became a pioneering figure in the development of house music at the now legendary Warehouse in Chicago, while Derrick May and Juan Atkins mirrored the industrial landscape of Detroit in their machine-driven techno.

New York also remained central in the development of this underground dance culture during the late 1970s and 1980s, with Larry Levan establishing the Paradise Garage as one of the scene's most important and influential venues, in the process inspiring many of the DJs who have since become some of dance music's most well-known figures, including Danny Tenaglia, David Morales and Junior Vasquez. In reference to the Paradise Garage, Fikentscher notes how "many members in the underground dance scene consider it to have constituted the epitome of social dancing as a celebration of individuality and community at the same time" (2000: 61).

All of these developments in the US became core components of the historical progression of dance music, and demonstrate how the foundations set in place by disco continued to be built upon by those in the underground, despite the fact the scene was still suffering from the disco backlash and had also been worn down by the impact of AIDS. ${ }^{3}$ Yet these developments did find commercial acceptance in the UK with the rise of the "acid house" phenomenon, the term having originally been applied to the electronic music being produced in Chicago. While American DJs and producers laid the groundwork, it was British DJs who took the music to a wider audience. 


\section{ACID HOUSE IN THE UK}

THE PHENOMENON OF ACID HOUSE essentially birthed the commercial, mainstream club culture of today. The underground developments in the UK's dance scene of the late 1980s centred on Manchester's Hacienda, and the work of its DJs Graeme Park and Mike Pickering, and on the Ibiza-inspired London clubs such as Shoom and Spectrum, set up by Danny Rampling and Paul Oakenfold. Reflecting the wider cultural impact of the US house music that was being imported into the UK and played at the Hacienda, indie bands such as the Happy Mondays and the Stone Roses incorporated dance rhythms into their music, tapping into the euphoria of the developing ecstasy culture. For a few years at the end of the 1980s and the start of the 1990s, Manchester became a musical melting pot of hybrid rock-dance bands.

In London, club culture was taking shape with the ventures of Rampling and Oakenfold, the latter now one of the most famous DJs in the world. Combining Chicago house and Detroit techno with the new sounds of British dance music, these DJs initiated the phenomenon of acid house. With its links to ecstasy and young people having a good time, a moral panic engulfed the mainstream, ensuring this new culture received attention from most of the media. Warehouse parties developed in its wake, and then outdoor raves, with many dance music fans latching on to the entrepreneurial spirit of Thatcher's ' 80 s Britain and setting themselves up as rave promoters, albeit in a blatantly illegal manner. While disco and house had been about experiencing the music in the confines of an established venue, raves represented something more unknown, held mostly in fields and therefore outside of the urban environment that had always contained this culture (see Gilbert and Pearson 1999: 29-31). Yet with the introduction of government legislation that increased fines for rave organisers, making it financially unviable to risk staging a rave, the majority of those involved in dance music returned indoors. This was compounded by the implementation of the 1994 Criminal Justice Act, which was intended to suppress the free party scene and curtail the activities of the country's alternative culture of "travellers, squatters and protesters" (Brewster and Broughton 2000: 402; see also Collin 1998; Gilbert and Pearson 1999; St John 2009).

\section{Superclubs, Superstar DJs and the Mainstreaming of Dance Music}

IF DISCO represented the mainstream's first engagement with DJ-based dance music, then the 1990s and the rise of superclubs perhaps constitutes some kind of second coming for dance music and DJs as a commercial force. After the UK government crackdown on rave culture, some of the more business-oriented minds in dance music took the culture back into clubs, developing a scene of branded nightclubs and big-name DJs, or as Reynolds describes, "a highly controlled and controlling leisure system" (1999: 382). In the process, the free-party scene of rave culture and the urban club scene became separated (Collin 1998: 228). The commercial potential of this music and its associated culture had been recognised. While companies such as London's Ministry of Sound and Liverpool's Cream 
have been criticised for their brash commercialism, it cannot be denied that they took dance music and club culture to a previously unattained level of mainstream popularity. For "underground elitists and acid house nostalgists" (Gilbert and Pearson 1999: 180), this may have represented a compromise of the anti-commercial ideologies of EDM culture, but the contemporary global prominence of these superclubs is a testament to their huge cultural impact.

Placing the DJ squarely at the centre of its marketing efforts, the music industry seemed to have learnt from the promotional errors it made in the days of disco. By making the DJ the star, the audiences had a figure to identify with, a recognisable face to link to the music, Haslam noting how "club culture is no respecter of artists, but it needed something to sell, a viable commodity" (2001: xxi). The DJ was now a brand, a signifier of a particular style of music, as well as a star worshipped in the same way as a rock or pop performer (Reynolds 1999: 275). Alongside this, the release of DJ mix-CDs, branded with the name of the DJ, enabled the industry to compile and package in album-form the individual, faceless tracks that characterise EDM. Sasha and John Digweed's mix for Renaissance in 1994 proved that such albums could sell in mass quantities (Phillips 2009: 124), establishing the template that Ministry of Sound, Fabric, Global Underground and several other companies have capitalised upon. Furthering this commerciality, some of these companies diversified their interests, spinning out from their brands such things as clothing, magazines, festivals, radio stations, record labels and more.

DJs aligning with this explosion of mainstream club culture, and who have achieved this superstar status, becoming figureheads for the global spread of house music, include Pete Tong, Fatboy Slim, Dave Seaman, Roger Sanchez, Carl Cox and Danny Tenaglia, amongst many others. Although this intensely commercial "super" bubble ultimately burst at the dawn of the new millennium amid criticisms of inflated club entry prices and DJ fees (Phillips 2009), club culture and dance music remains very much within the mainstream. The current ubiquity in the global pop music world of EDM producers David Guetta and Stuart Price exemplifies this, their services having been employed by artists such as Madonna, Black Eyed Peas, The Killers, Seal, Scissor Sisters and Take That. The mainstreaming of this music has a social, cultural and industrial significance, and what I find interesting are the processes and mechanisms in place in particular scenes that have facilitated this mainstreaming. One area where these can be seen is in the prominence of EDM festivals in Sydney.

\section{The History of EDM Culture in Sydney}

THE HISTORICAL development of dance music culture in Sydney is intrinsically linked to the acid house phenomenon and warehouse party culture that developed in the UK in the late 1980s. Murphie and Scheer (1992) outline some of this history, while also raising certain issues in relation to the position of the Australian dance scene within global dance culture (see also Harley and Murphie 2007). Describing the dance scene in both cultural and economic terms, their chapter provides a background context which aids in understanding 
the contemporary scene. Reference is made to the role of Sydney's gay community in popularising dance music in the city and the way "a lot of the values of gay dance were to follow through into inner city dance party cultures" (1992: 174). The decline of Sydney's pub scene is also noted as helping to further this popularisation of dance music. In sketching a brief history of Sydney's dance scene, and then discussing the tension between the "local" and the "global", and how "in the broadest sense Sydney dance parties are simulated after a notion of Euro-American antecedents" (1992: 180), the chapter stands as a model on which to base an ethnographic study of Sydney's EDM culture.

Murphie and Scheer suggest that at the turn of the 1990s Australian dance culture became more of a "mainstream" concern, describing how "1990 was the year in which the market took over the last vestiges of lived cultural specificity in dance culture" (1992: 177). Dance music began to filter into the commercial pop charts, and numerous clubs and record stores catered for an increased consumer demand. In turn, this cultural shift by the music into the mainstream led to an eradication of the "dance parties' power to signify as radical, or even as avant garde fashion" (1992: 178; authors' italics). Writing in regard to Australia's adoption of dance music, they suggest that "what may have functioned as subcultural 'noise' in Manchester or New York, was often already reconstituted as mainstream 'signal' by the time" (1992: 172) it reached Australia.

Therefore, Murphie and Scheer "characterise this appropriation of subcultural meanings from the UK dance scene as aesthetic and affective" (Gibson and Pagan 2000: 10), rather than involving any kind of explicit political ideology of protest or subversion. This appropriation can be seen in the example of the early dance parties that took place in Sydney and that developed out of the gay dance events held at the Hordern Pavilion, ${ }^{4}$ in that they were based on UK models of the warehouse party and as such formed a connection with dance culture outside of Australia, although in their legal nature "the parties themselves were not the equivalent of the illegal English events they were supposed to be modelled on" (Murphie and Scheer 1992: 175). Sydney DJ Goodwill acknowledges the impact British dance culture had on the development of Australian dance culture, explaining how "English people used to have a massive influence on the Australian scene ... they brought it here pretty much". 5 This is not to say, however, that those within the Sydney scene simply imported and copied a foreign culture, for, as Collin explains, "as the acid house formula was exported overseas, it began to assume local characteristics and cultural influences" (1998: 277).

While warehouse raves and parties represent a separate scene to club nights and festivals, the commercial house music cultures that developed in both the UK and Australia during the 1990s have their roots in these raves. Companies such as Ministry of Sound, Cream and Renaissance took the musical and cultural foundations of rave culture and built ultracommercial enterprises around the concept of dance music culture as a lifestyle choice. While originating in the UK, these brands of dance music have had an impact in Australian EDM culture, releasing CDs, staging club nights and festivals, and in the case of Ministry of Sound, establishing a local arm of the record label. The posters below demonstrate how these overseas brands are used to market EDM events in Sydney (see figs. 1-4). 


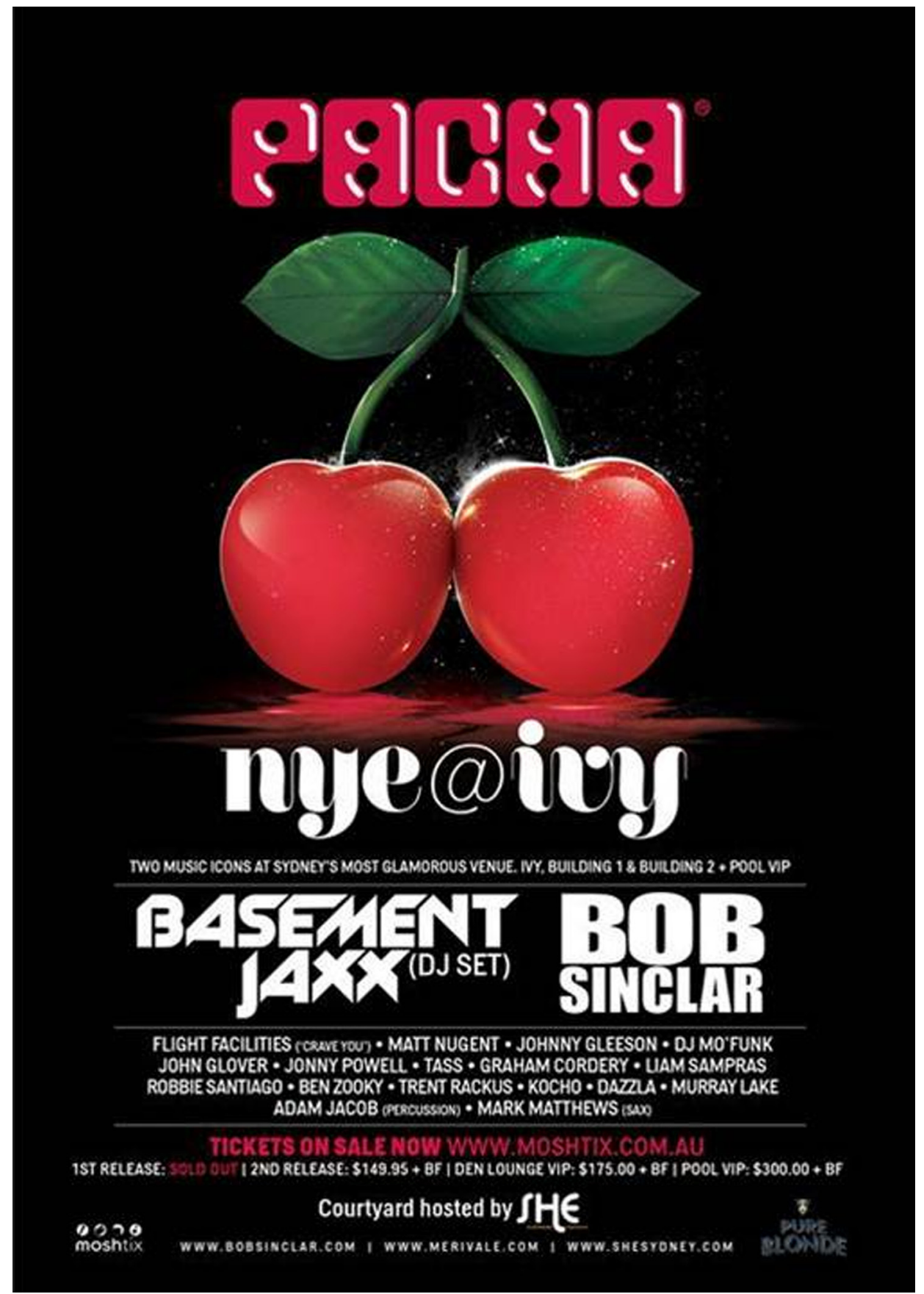

Figure 1. Promotional poster for New Year's EVe 2010 at IVy Nightclub 


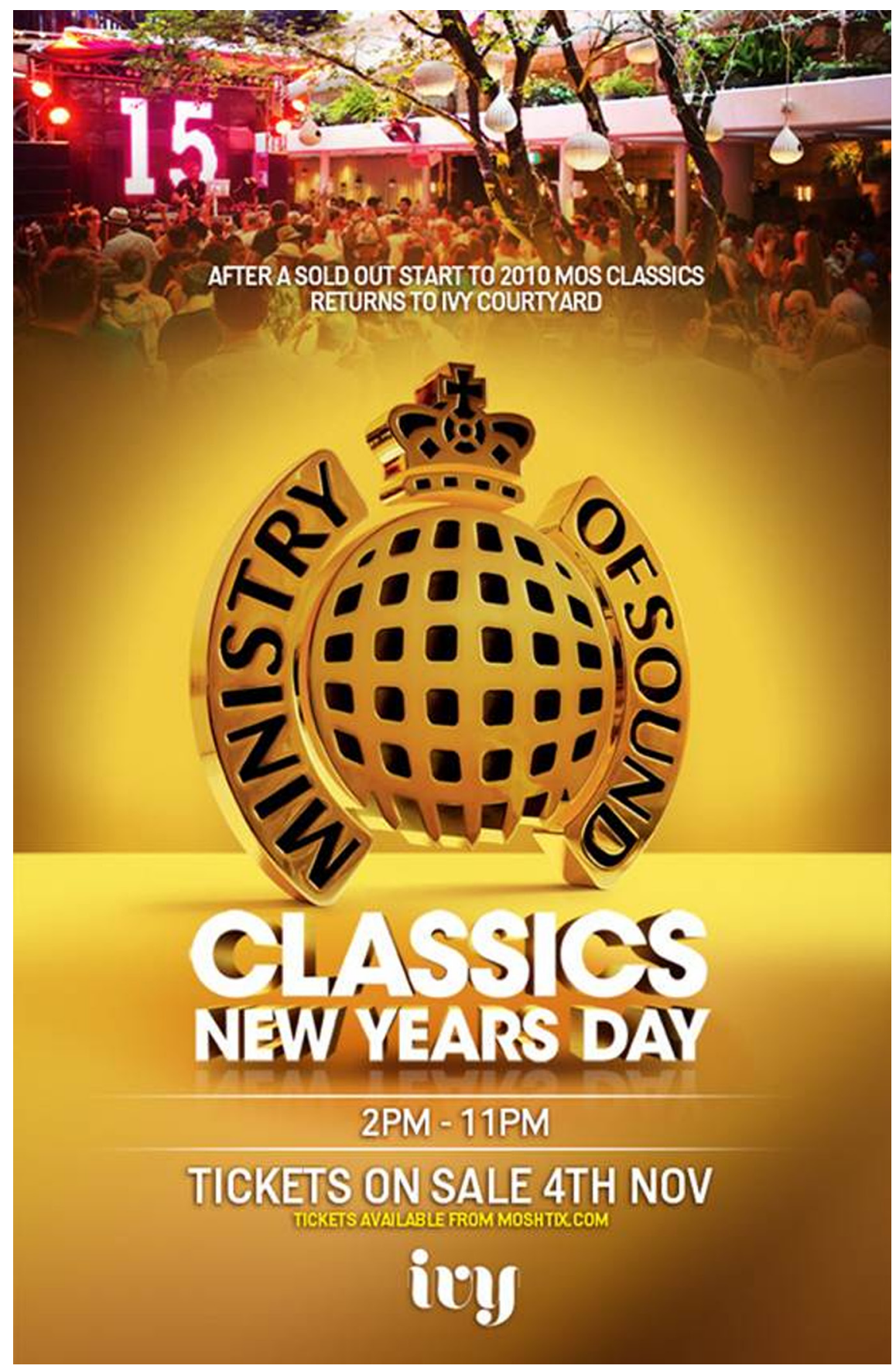

Figure 2. Promotional poster for New Year's Day 2011 at IVy nightclub 


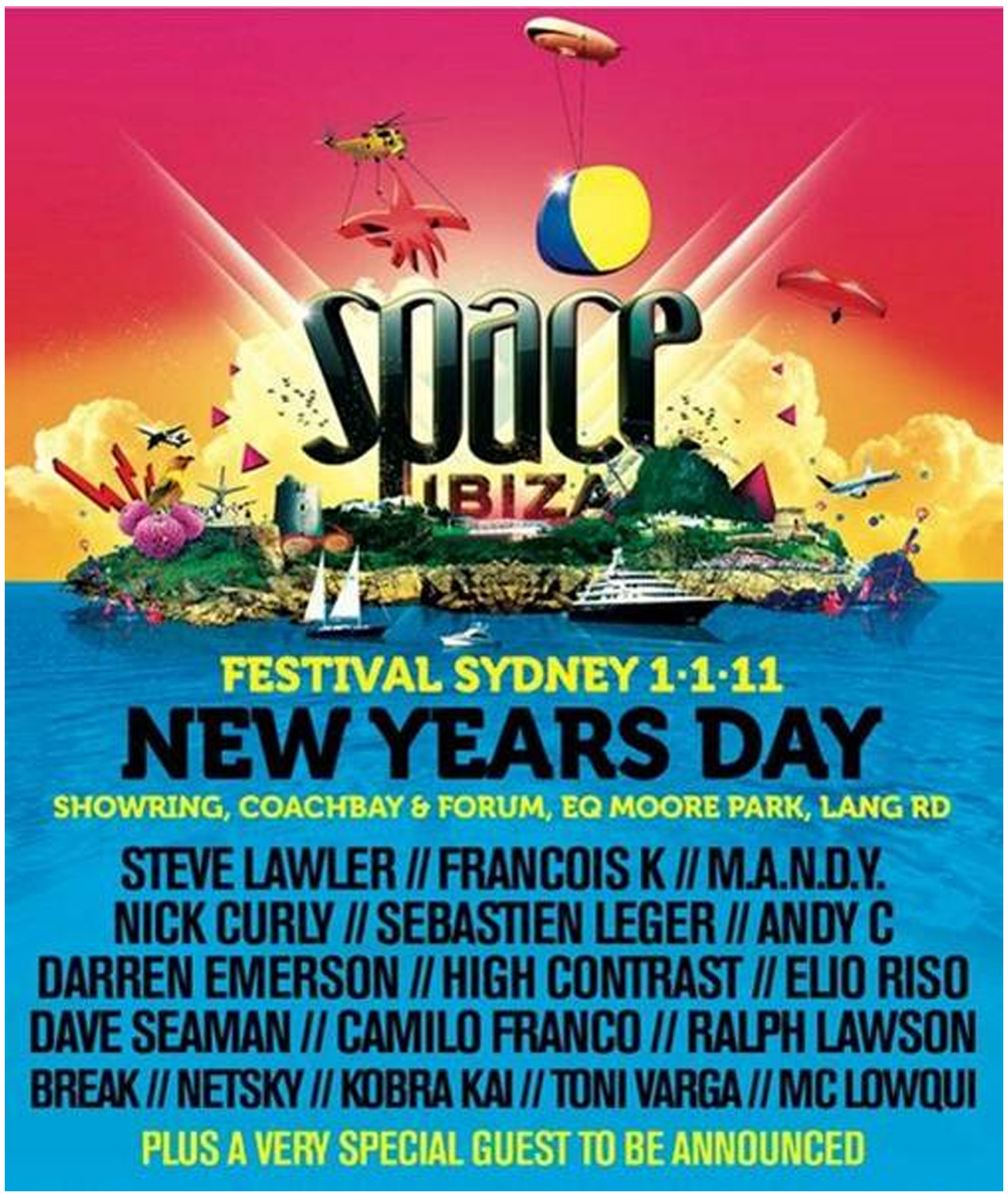

Figure 3. Promotional poster for Space Ibiza festival New Year's Day 2011 


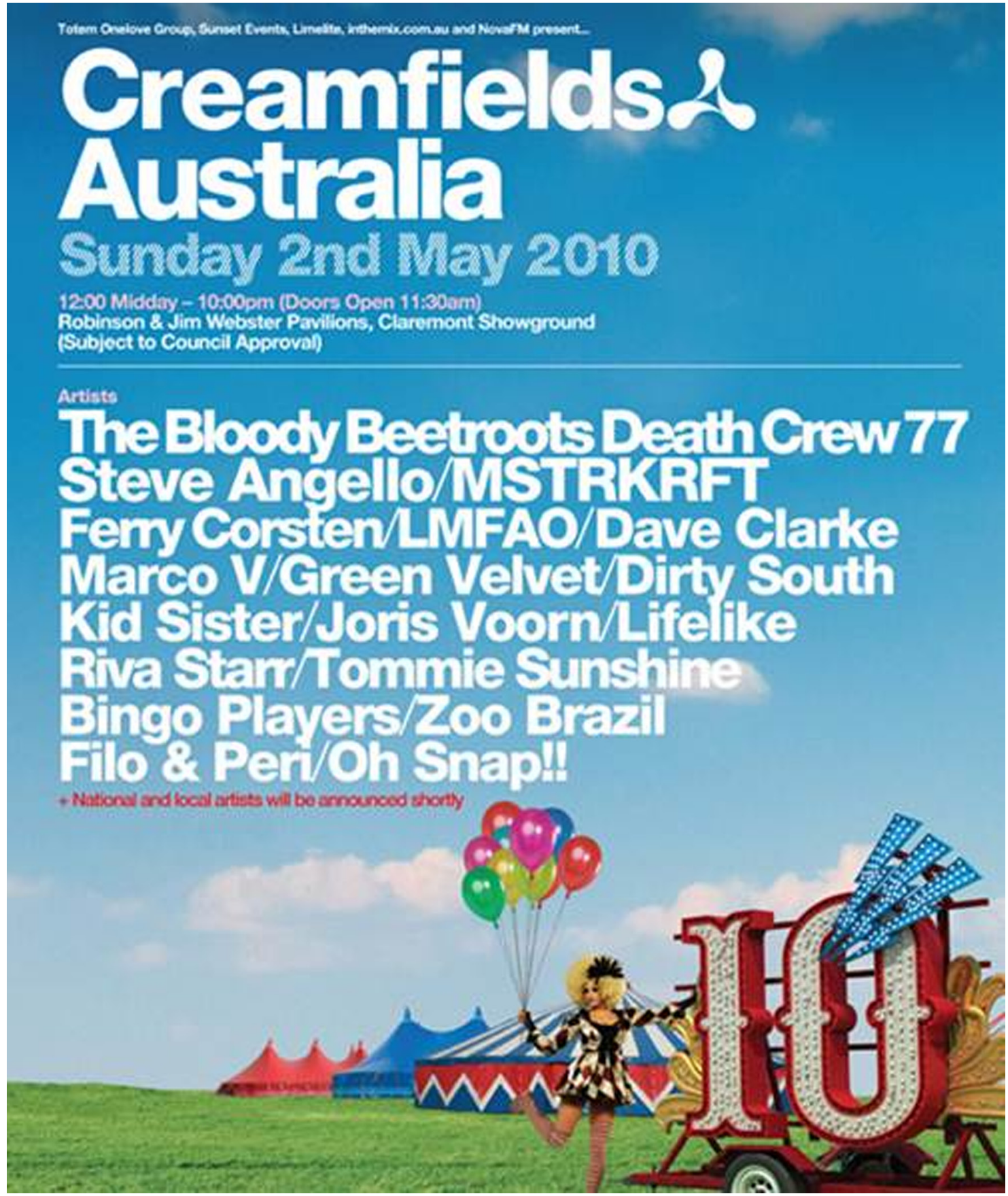

Figure 4. Promotional poster for CreamfieldS 2010 


\section{The "Mainstream" and the "Underground"}

THE TERMS "mainstream" and "underground" are used extensively within EDM as part of the way participants ideologically construct and make sense of the scenes and culture in which they are involved. Indeed, the terms have a rich history in the wider scheme of social and cultural expression and rebellion (Fikentscher 2000: 9-10), and more specifically in relation to subcultures, music and youth activity. As such, the terms have received rigorous interrogation, critique and analysis. One of the most detailed considerations in relation to EDM can be found in Thornton's text on club cultures (1995), while more specifically Fikentscher provides a rich and detailed socio-cultural study of underground dance music in New York during the late 1980s and 1990s (2000).

In many of the interviews I have conducted with DJs in Sydney, the "underground" is seen to have less emphasis on commerciality and as providing a platform for playing more obscure music. Some DJs linked the role of the underground DJ to "educating", and suggested that contrasts with the role of the more commercial DJ who has to "entertain". Of course, the events, scenes and styles that represent the underground and the mainstream are diverse, and cannot simply be separated into two opposing camps. Those involved in the underground are not totally divorced from commercial concerns, while those in the mainstream are not necessarily chasing large audiences and financial reward. Yet typically, within the discourse that surrounds EDM culture, the "mainstream" club scene is positioned as an over-exposed and musically non-inventive element of this culture, and as consisting of a stagnant, uncreative and unchanging "mass" (Thornton 1995: 94), while the "underground" scene is described as providing a "fertile breeding ground for new house music's diversification and regeneration" (Bidder 2001: 245). Fikentscher provides a succinct definition of the latter term, noting how activities of the underground "can be said to take place in a limited space, inhabited by a limited number of participants who may establish various mechanisms to further the longevity of their activities" (2000: 10).

He goes on to explain how one crucial aspect of this is the circulation of insider knowledge, and that participation in the underground is determined by one's "musical connoisseurship" (Fikentscher 2000: 10). It is generally assumed that the mainstream draws its musical and stylistic content from the underground, giving wider exposure to that which has a degree of proven popularity. Inherent within such a view are the beliefs that "powerful new sounds emerge from the margins and challenge existing musical conventions" (Negus 1996: 28) and that "where commercial interests are involved, a sense of the innovative in music scenes is lost" (Connell and Gibson 2003: 102).

Thus, the invention and progression of dance music is situated as occurring out of the view of most of its participants. Sydney DJ Goodwill acknowledges that there is an identifiable divide between underground and mainstream dance culture, and makes reference to how "there is a large amount of cynicism from the underground criticising the overground DJs who will play anything", ${ }^{6}$ and, as Sydney DJ Trent Rackus suggests in regard to the negative views and attitudes that exist towards commercial dance culture, 
"no one wants to be mainstream, do they?". ' Such negative perceptions of the mainstream and commerciality are a constant feature of underground cultures, and permeate much of the discourse surrounding the development of EDM. In the same way that the concept of the underground is often aligned with a less commercial approach, the current mainstream popularity of dance music is perceived as having negatively affected the quality and cultural value of this music. Indeed, the perceptions and ideals that surround popular music culture as a whole typically equate increased commercial success with decreased artistic worth, and feed into the well-worn debates around authenticity and the dichotomies between major labels and independent labels, live performance and miming, and rock and pop music (Shuker 2002: 20).

The suggestion here is that the culture has been compromised in some way by its gradual increase in popularity, and also that prior to this commercialisation it was somehow a "pure", "original" and non-commodified art form. Collin argues that, as dance culture "became part of the pop mainstream, some of its unique mystery - the special secret - had been lost forever as it entered the public domain" (1998: 276), while Haslam suggests that the dance music infrastructure of superclubs, media, promoters and trade fairs that underpins contemporary club culture "is as much about money-making opportunities as anything else ... once money moved in, dance culture became compromised" (2001: 205). St John describes superclubs as representative of "corporate clubbing", and makes reference to how, by the mid-1990s, dance music had become "a hyper-commercial global phenomenon bursting with brand recognition” (2009: 11).

\section{EDM Festivals IN SyDNEY}

IN THE WAY they are staged during the day, in public spaces such as parks and cultural quarters, festivals make evident the increased mainstream acceptance of EDM. With its associations with night-time and therefore the dark and seedy territory of the club, the music and culture always had a slightly rebellious edge that made them seemingly unfit for mainstream consumption, amplified by their associations with illegal drug taking. Yet the abundance of these festivals in the Sydney CBD and immediate surrounding suburbs certainly situates the EDM scene within the wider cultural mainstream of the city. Promotional posters for the festivals adorn lampposts, telegraph poles and billboards all around the city, the mainstream media carry advertisements for the events, and when the festivals eventually take place, their sounds can be heard drifting around the city's eastern suburbs. Below are brief descriptions of Sydney's major commercial EDM festivals.

\section{PARKLIFE / FIELD DAY / HARBOURLIFE}

These festivals are staged by John Wall under the corporate banner of Fuzzy, and are three of the most popular annual dance music events in Sydney. Establishing the company in 1996, Wall was well placed to capitalise on the commercial boom in dance culture that occurred with the development of the superclubs and the superstar DJ phenomenon. 
Parklife is currently held at Kippax Lake in Moore Park, a few kilometres outside the city's CBD, on the first Sunday of October. Since 2007 the festival has also travelled interstate to Adelaide, Brisbane, Melbourne and Perth, playing to a combined crowd of over 100,000. After several years promoting successful club nights and events, Wall and business partners Ming Gan and Adelle Robinson decided to stage an outdoor clubbing-based event, with the first Parklife taking place in March 2000. As smoking was still permitted in clubs in the time, the idea was to stage a smoke-free club-like party in an outdoor context that would potentially benefit from Australia's warm climate. While the first event was by no means a commercial success, with approximately 700 tickets out of 2000 sold, and with torrential rain for most of the day, it set in place the template that has now become the standard for many daytime dance music parties in Sydney. Discussing the first Parklife and subsequent parties he has staged, Wall describes how,

Because we had sold so few tickets, we had a tent and everyone that went easily fitted in the tent, so it didn't matter that it was raining, they had a great time! So it wasn't a dead loss, because the next year did alright, started making back the money and improving the whole thing, and now Parklife has been getting bigger every year. This year looks like being fifteen thousand people. Then, because we had done Parklife and managed to impress Centennial Park, we'd been hassling the Botanic Gardens to let us do parties there for years, and they'd said "No, no, no". But then after we did Parklife, and we hassled them even harder, finally they said "Alright" to our proposal for a New Year's Day party, which became Field Day, and that did much better than we expected. ${ }^{8}$

Field Day is an annual dance music event held in Sydney's Domain park area in the CBD on New Year's Day, and is one of the key events in the Sydney EDM calendar, with a capacity of 25,000. First taking place in 2002, the event regularly sells out weeks in advance, and has become something of an iconic event for Sydney clubbers, attending at least one Field Day being a rite of passage. Harbourlife is held annually at Sydney's Fleet Steps area at Mrs Macquarie's Point, adjacent to the Botanic Gardens and overlooking the harbour. It typically takes place on the last Saturday in November, and has been staged every year since 2003. With a capacity of only 5,000, the event is usually a sell-out.

\section{GOOD VIBRATIONS}

This annual festival is staged by Jam Music, which is part of Justin Hemmes' Merivale Group, a Sydney-based hospitality company that operates various bars, clubs and restaurants around the city, such as Establishment, Slip Inn and Tank. Held in February, the event developed out of another festival called Vibes on a Summer's Day, with the first Good Vibrations taking place in 2004. In Sydney, the festival is held in Centennial Park, and also travels interstate to Melbourne, Perth and the Gold Coast. The capacity of the event in Sydney is approximately 35,000 . 


\section{WE LOVE SOUNDS}

Held in the venues that are part of the Entertainment Quarter on the Fox Studios site, a few kilometres outside of the CBD, this festival is staged on the Saturday of the Queen's Birthday long weekend in June, originating out of an event in 2004. It is therefore the only EDM festival to take place in winter. In 2010, the festival was also scheduled to take place in Adelaide, Auckland, Brisbane, Canberra, Melbourne and Perth, although the Perth event was cancelled due to lack of interest, ${ }^{9}$ while the Auckland leg took place with a reduced line-up.

\section{FUTURE MUSIC}

Staged by Mark James' Future Entertainment company, this annual festival takes place in Adelaide, Brisbane, Melbourne, Perth and Sydney during the first two weekends of March. In Sydney it is held at Randwick Racecourse, the first Future Music being staged in 2006, and it has quickly established itself as one of the most popular EDM festivals in Australia.

\section{STEREOSONIC}

Commencing in 2008, this is a relative newcomer to the Australian festival calendar, and is another national event that stops at Adelaide, Brisbane, Melbourne, Perth and Sydney during the last weekend of November and the first weekend of December. In 2010 the Sydney event took place at the Sydney Showground site at Olympic Park at Homebush, having previously been staged in the Entertainment Quarter of Fox Studios, the move being a response to criticisms of over-crowding. The festival is operated by the two major Australian EDM promoters Hardware and Onelove, the latter name also established as a well-known brand of Australian club culture with associated club nights and mix-CDs.

\section{CREAMFIELDS}

Also staged by Hardware and Onelove, this festival was a new addition to the Australian scene in 2010, although the name has a much wider history within EDM culture. The name is licensed from the UK company behind the annual Creamfields festival in the UK, which grew out of the famous Liverpool-based superclub Cream. While the UK version is held over an entire weekend, the Sydney event is only staged on one day, although the festival also travelled to Brisbane, Melbourne and Perth. Again, the Sydney site used was the Entertainment Quarter at Fox Studios. The use of the name represents the branding that dominates contemporary EDM culture, the Cream brand having immense cultural value in the perceptions of clubbers. By utilising the brand for the festival, the Onelove group are instantly tapping into that value. This guarantees an audience for the event, and reduces the work associated with building a festival from the ground up. While a line-up of reasonable quality needs to be provided, the name itself works to lure EDM participants. 


\section{Pushing Dance Music into Sydney's Mainstream}

THE PROGRESSION of Sydney's dance music culture into the mainstream has been facilitated by a number of different factors, including DJs, promoters, industry support, legislation and media. Festivals are another factor that can be thrown into this mix. As John Wall acknowledges, the large dance festivals he has put on in Sydney have, in part, been responsible for furthering this mainstreaming of the city's dance scene:

Yes, to an extent [the Fuzzy parties have helped to push dance music into the mainstream] ... I think you can't deny us doing a party as big as Field Day [has had an effect]. The first year it was all dance crowd [sic], but inevitably other people are going to notice it because it's so conspicuous. So that kind of thing would be making some difference. You get all these DJs who once upon a time would have been considered pretty underground, playing in front of people who are not necessarily underground, and I think it's good to expand people's horizons in that way, even if it does make a scene more commercial. ${ }^{10}$

While festivals in themselves are nothing new, it is obvious that in Sydney festivals have become an important part of the EDM scene in the past decade. I would suggest this stems from a number of factors, one being the scene's infatuation with international DJs. These DJs dominate the festival line-ups and are used as a central marketing strategy in the promotional material for the events, with discussion on the value of international DJs constantly circulating within the scene. ${ }^{11}$ The festivals also represent a continuation of the branding that has dominated commercial club culture over the past fifteen years, with the names of established festivals such as Parklife and Future Music becoming branded representations of EDM culture in Sydney and Australia. As part of this, I would suggest the festivals reflect the commercialism of the scene, as well as an increased professionalism in the way the scene operates. All of this has served to broaden the appeal of the scene, making the music and culture seemingly more mainstream and attracting bigger audiences.

Also of interest is the growing diversity of the line-ups of these festivals. Events such as Field Day, Parklife, Good Vibrations and Harbourlife were established as EDM festivals, and previous headline acts have included DJs such as Felix Da Housecat, Fatboy Slim, Martin Solveig and Roger Sanchez. In 2010, this focus on exclusively EDM artists has shifted. As can be seen in the posters below, the line-up for Parklife featured hip-hop legend Missy Elliott, alongside indierock bands The Dandy Warhols and The Wombats, while Harbourlife was headlined by The Temper Trap, an Australian indie-rock band from Melbourne currently making inroads on the international market. Thus, some of the stylistic barriers that previously distinguished EDM festivals in Sydney are breaking down. Australian music festivals such as the Big Day Out have for many years accommodated both rock and dance acts, with the Boiler Room stage hosting DJs and acts such as Sasha, Carl Cox and Underworld, and many other festivals have eclectic and diverse line-ups. Yet festivals in Sydney such as Parklife that have always been associated solely with EDM have rarely crossed over into other, non-EDM genres. This represents a further significant shift in the shape of dance music culture in Sydney (see figs. 5-6). 


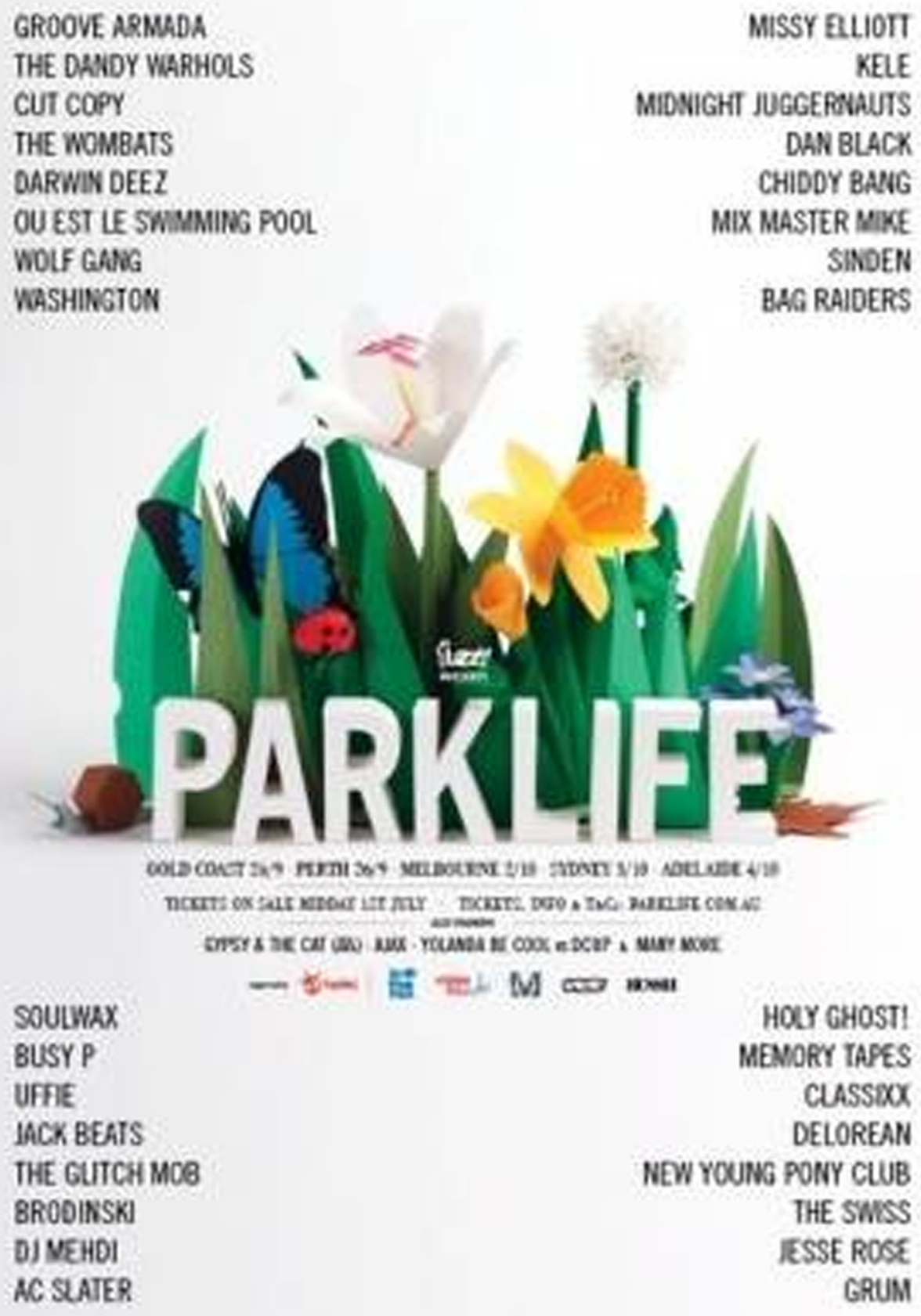

Figure 5. Promotional poster for Parklife 2010 


\section{THE \\ TEMPER TRAP}

HARBOURLIFE Saturday 20th November 21000

Metronomy Yacht Club DJs Knightlife and mary inere

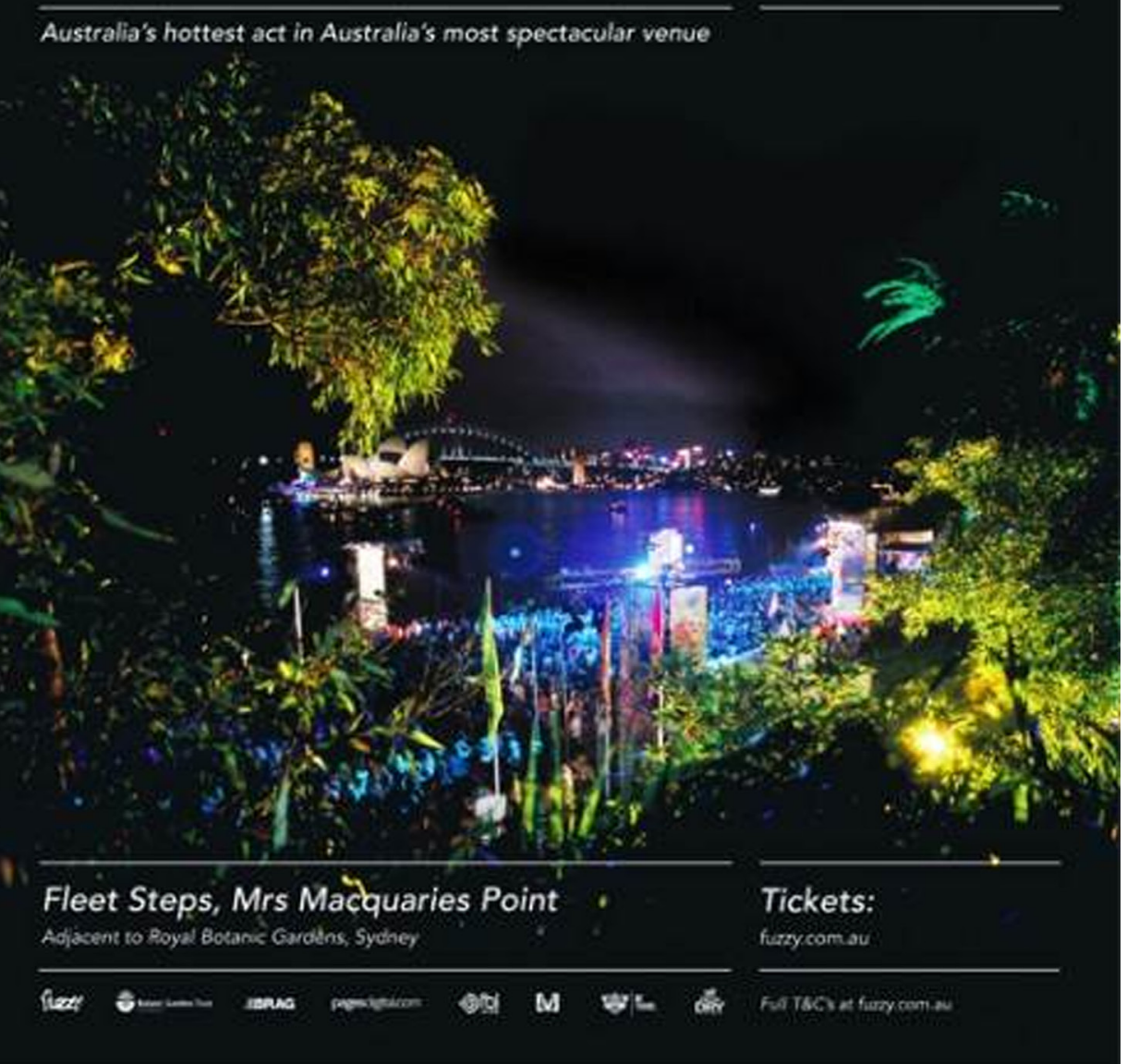

Figure 6. Promotional poster for Harbourlife 2010 
Adding stylistically diverse acts to a festival has the potential to broaden its appeal and attract a greater audience, yet at the same time it runs the risk of alienating and confusing the festival's traditional audience who view the event as dance music oriented. The cancellation of a planned leg of Harbourlife on the Gold Coast on the last weekend of November suggests that the audience were not quite willing to accept the idea of an indie-rock band headlining a house music festival. ${ }^{12}$ The announcement of the line-up for Field Day 2011 was promoted with an initial teaser quote on the Fuzzy website ${ }^{13}$ that described the "ever-merging worlds of electronic, indie rock and hip hop". In regard to this, John Wall remarks that:

People's tastes are very diverse these days. It's not like when we first started promoting in the' 90 s where you picked your side - rock or dance — and you thought everyone on the other side was an idiot. People don't think about music that way anymore. We've noticed our customers don't make that distinction between a DJ or a live band. ${ }^{14}$

This perception of "merging worlds" and "diverse tastes" can be seen in the artists selected to play Field Day 2011, with the line-up featuring more band-based acts than ever before (see fig. 7).

The selection of acts for Field Day 2011 continues the broadening out of the music focus of the key Fuzzy events. For the first few years of its life, Field Day was a solely EDMfocused festival, with a line-up featuring nothing but DJs. As the poster demonstrates, the event has now developed into something with a greater musical diversity, with the inclusion of hip-hop stalwarts Public Enemy, Australian psychedelic rock band Tame Impala and British pop singer Marina and the Diamonds.

All of these festivals are competing for the disposable income of Sydney's EDM fans. In a crowded festival market, every promoter has to ensure their event stands out. While the line-up is obviously the most important aspect here, other factors such as location and time of year can attract or deter potential audiences. Fuzzy perhaps take the most idiosyncratic approach with their line-ups, combining a selection of big ticket acts with more obscure artists. With Fuzzy, an educational ethic is embedded within their festival music policy. Explaining how he tries to make his events unique, John Wall states,

Musically we don't try to be all things to all people... We put on artists who are big names that people have heard of but more importantly pushing the sounds that we like and new artists that we like. Right from when we started Fuzzy in the mid '90s we were always about not simply preaching to the converted, we like to actually convert people. $^{15}$

This approach became most apparent in the first half of the 2000s, when breaks became popular among clubbing crowds in the city. Wall's initial breaks parties lost money, but he persisted with eventually successful attempts to take this music to a wider audience in Sydney. 


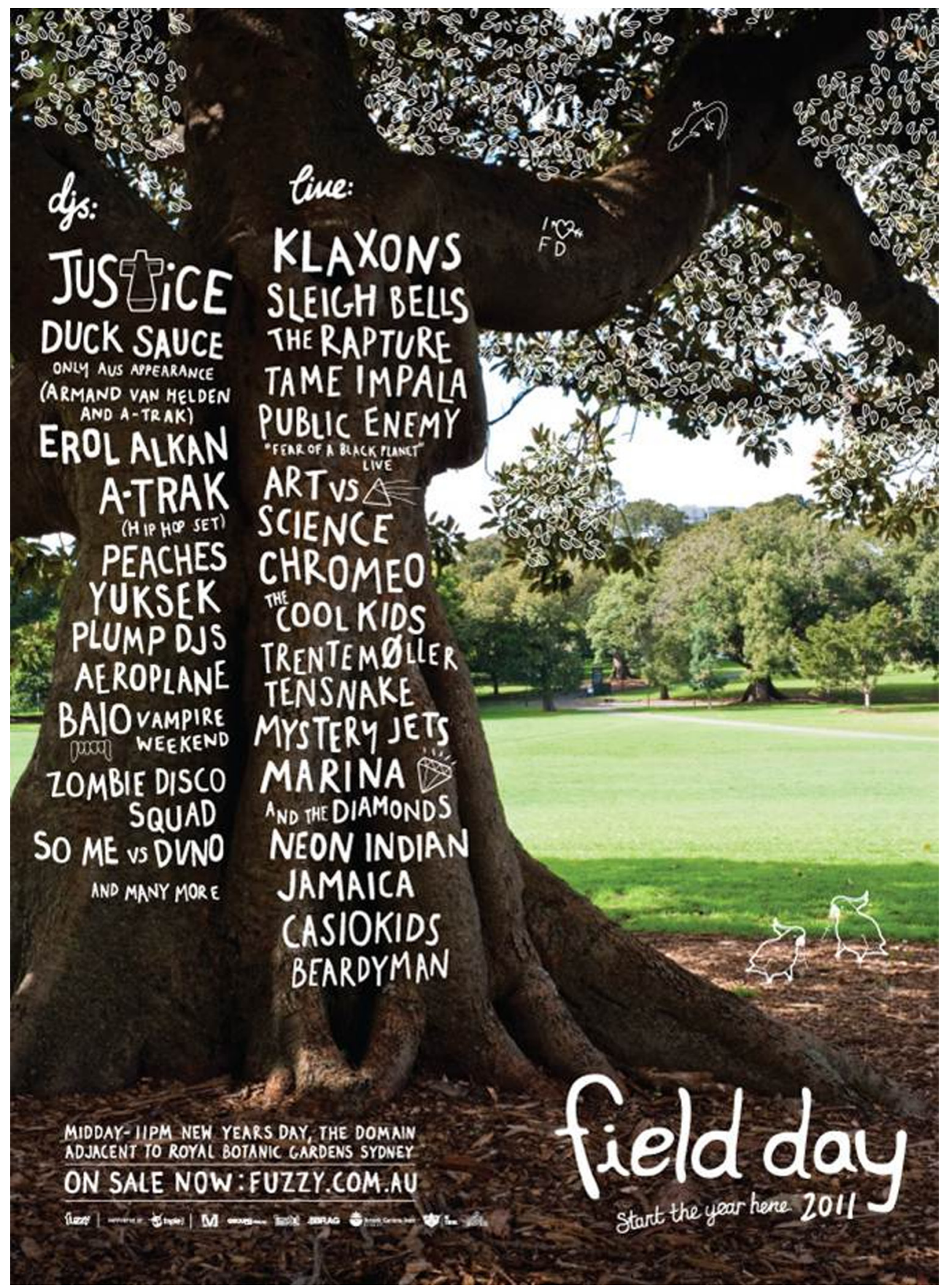

Figure 7. Promotional poster for Field Day 2011 
Sydney breaks DJ Kid Kenobi became the most popular DJ in the scene, being voted number one in the inthemix Top 50 DJ Poll in 2003, 2004 and 2005, while international breaks DJs and producers such as Krafty Kuts and the Plump DJs headlined various festivals, and Ministry of Sound released a selection of breaks compilations. Through the Fuzzy parties he staged early in the decade, Wall is considered to be a key figure in popularising breaks within Sydney:

In early'96 I felt like there were a lot of gaps in the market. Very few people were doing breaks, which was something that I was really into, and I thought that, particularly given that there were things coming out like the Chemical Brothers, that sound ought to be much more popular than it was. So I just started promoting. I actually didn't do breaks first because I thought we needed to do something that would get a decent number of people, otherwise we'd be out of business in a week. So our first party was seventy per cent house, and then thirty per cent breaks and trip-hop and whatever else was around at the time. That was in August '96, and it went really well and sold out, so it was a pretty good start... We focused everything we did on trying to make that happen... I'm not trying to take sole credit for it, but we did just decide we are going to see if we can make breaks bigger, and we just kept going and kept going and kept going until it was. ${ }^{16}$

Due to the fast pace at which EDM culture moves, breaks eventually lost its wide appeal in Sydney, with electro taking its place as the sub-genre of the moment during the mid2000s. Yet, its brief period of popularity demonstrates how promotional efforts can shape a scene. Without the deliberate attempts by Fuzzy to push this style through staging parties dominated by breaks-related artists, it is doubtful to have garnered such acceptance within the scene. In presenting the music to a wider audience, Fuzzy facilitated the development of the breaks scene in Sydney. More broadly, this reflects how festivals in the scene can create and shape tastes and audiences.

\section{The Effect of Festivals}

THERE has been extensive discussion in the local EDM media on the variable impact of festivals on Australian club culture. The Australian dance music website inthemix.com.au (ITM ${ }^{17}$ recently posted a five-part feature on the current state of the EDM scene in Sydney and Australia, based around interviews with various local DJs and promoters. ${ }^{18}$ Together with the user comments posted in response, the feature made for particularly interesting reading, and included some reflections on the impact of the big festivals that are worthy of further consideration.

Observing responses on ITM from various industry personnel to questions regarding the current state of EDM scenes in Sydney and Australia, it becomes clear that festivals are perceived as causing a decline in the number of clubbers attending club nights. In the mid-2000s, the Sydney scene bustled with regular weekly nights such as Together at Home and Kink at The ArtHouse, the latter held in such high esteem by clubbers in the city that 
a recent Facebook campaign successfully persuaded Kink promoter Scott Robertson to organise a one-off reunion night. Yet he refused to take this as a sign that Kink could make a permanent comeback:

The Kink reunion Facebook group that started came as a big surprise to me and all our old residents and was very humbling. It really is testament to how special the family atmosphere was at Kink. Does this make me think there is a gap in the market for Kink to return to the weekly club scene? In all honesty, no. Will this be the last we see of Kink? Probably not. ${ }^{19}$

This hints at a future for the Kink clubbing brand that is based around irregular, one-off special events, rather than weekly clubbing nights, an outcome that can partially be ascribed to the dominance of festivals in the scene. Robertson also puts this down to a shift in the way clubbers engage with the culture of the scene:

The new generation of kids that have come through seem to be a lot less loyal to club nights and venues, making it harder for promoters to sustain their nights. Sydney as a whole has become more and more motivated by free entry and cheap drinks and is a lot less motivated by music. Furthermore, every man and his dog seems to think he is a DJ and as long as they can bring mates, they will get booked by the new breed of young promoters who don't really care about programming, building a brand or music policy. And so the downward spiral continues. ${ }^{20}$

There are now no weekly events that compare to the success Kink enjoyed, although the recently launched Saturday night Pure Ivy at Justin Hemmes' The Ivy in the CBD represents an attempt to reorient the mainstream Sydney house scene back to weekly club nights. The long-running Saturday night Chinese Laundry (held at Slip Inn in the CBD and regularly featured in DJ Mag's Top 100 Clubs in the World poll), ${ }^{21}$ with performances from a broad range of both big-name DJs and more underground DJs, is also managing to weather the storm of festivals. Still, the perception that the weekly club scene is in dire straits remains, as made evident in the following quote from Sydney promoter, DJ and co-founder of the We Love Sounds festival Ben Korbel, in response to being questioned on the changes in the Australian dance music scene during the past ten years and the current state of weekly clubbing:

One of the major changes for me is the shift from a smaller subculture and a club scene with more of an independent flavour to a very strong festival scene across the whole year. It's like clubbing on steroids... it has certainly meant that clubs shrink back into their cave. That's not to say there are not good things that happen in clubs, but they're probably one-off events or monthly parties. There's much less of a culture of people partying every Saturday night, or if they do, it might be at a bar with a DJ... I think everything is cyclical. The festival market will correct itself. As that happens, people will have had too much of a good thing. Things will move back into smaller venues. It's already happened with live music, people will still go out to small venues. The problem is specific to electronic music at the moment. ${ }^{22}$ 
It is interesting to note here Korbel's framing of the dominance of festivals as a "problem", as if it is something that needs rectifying and correcting in order to rejuvenate the local scene. This comment seems even more surprising when one considers Korbel is a festival promoter himself. In light of recent events, however, it is clear that Korbel and his team have struggled to compete in the crowded festival market, with the Perth leg of 2010's We Love Sounds cancelled due to low ticket sales, and the company behind the festival going into liquidation due to losses incurred during the run of festivals this year. In response to the liquidation, Korbel comments:

The biggest festivals, for the most part, are selling out, however much more slowly, and some major players are barely breaking even now on their usually multi-million dollar events. When We Love Sounds launched, there was a relevant place for it in the market, however as new festival after festival entered the market, ticket buyers have become saturated with large-scale events with large-scale line-ups. In order to survive as a business, we went with 'bigger is better', even though our core philosophy was not aligned with this in any way. Sadly business health and artist vision do not always align. ${ }^{23}$

While multiple factors contribute to the collapse of a business, one of the major problems is the over-abundance of festivals available for clubbing audiences in Sydney and Australia as a whole. The rise in popularity of these events is not unique to EDM culture, with several music-related festivals promoted around the city and the country, although with some struggling to sell tickets and some being cancelled. ${ }^{24}$ This has led to suggestions of an "over-saturation" of festivals, and that there are simply too many festivals for the market to sustain. This smorgasbord of festivals has also driven up artist fees. In a scene with numerous promoters fighting for the services of a handful of big-name international acts, these acts have been able to demand an increase in their appearance fees. As Fuzzy promoter John Wall explains:

It's definitely an over-saturated market at the moment, but we're just doing everything we can to make sure Parklife is as good as you'd expect, but hopefully even better. The cost of a line-up has gotten crazy because there's five times as many promoters trying to get artists. There aren't magically five times more artists in the world. Prices have gone up enormously and everyone is fighting to get the best line-up. This year's line-up will be costing us five times as much as the line-up two years ago and double that of last year's. We're expanding slightly but mainly it's all the competition. We have a joke with agents overseas that when they get a phone call or email from an Australian promoter, it's like 'ka-ching!'25

This increase in line-up costs is also highlighted by Wall's business partner and Fuzzy cofounder Ming Gan, who references the electro-heavy line-up for Parklife 2007 that featured Justice, Digitalism and MSTRKRFT, to emphasise the pricing effects of the mass of festivals: 
With more festivals and less artists that sell tickets, artist fees have gone through the roof... something is going to give. If you've got a festival that's paying a ridiculous amount of money for one artist they think they need to survive, but they don't achieve that, it's going to fall apart... If we were to price that line-up now, we'd be paying four times the amount. ${ }^{26}$

\section{CONCLUSION}

I BEGAN this article by tracing some of the historical development of dance music, identifying the moments where this essentially underground style became absorbed into the mainstream. This history provides a wider context in which to place the recent developments in EDM culture in Sydney, with an emphasis on mainstream, branded club events and festivals. These developments, I believe, represent a breaking down of the barriers between the underground and the mainstream. These festivals, with their expansive line-ups, draw diverse crowds. In addition, the number of EDM day festivals represents a shift in the activities of clubbers in Sydney away from the traditional EDM environment of the night-time club. While the effect they are having on regular club nights in the city is a justifiable concern for some, it is surely a positive for the scene in the way the festivals have embedded EDM within the city's mainstream cultural landscape. DJs, promoters and clubbers have taken their lifestyle to a much wider audience through these events.

Furthermore, the growing musical diversity of the line-ups of some of the festivals is significant. In an attempt to distinguish its events in a crowded festival marketplace, Fuzzy has broadened its music policy, bringing in indie-rock and hip-hop live acts. Of course, many EDM fans do not only listen to EDM music, and so the line-ups make sense. At the same time, this diversity is something new for festivals in the city that have developed within EDM culture. It would seem that the boundaries between styles and audiences are becoming increasingly blurred, or perhaps more appropriately, increasingly fuzzy (Fikentscher 2000: 51).

The Sydney EDM scene may have shifted permanently to a scene dominated by festivals rather than clubs. The fast-moving and ever-changing shape of EDM culture suggests that these festivals simply represent one in a long line of trends. Perhaps clubbers will rediscover the long-term familiarity provided by regular weekly nights. The festivals certainly represent a significant shift in the orientation of EDM crowds in the city, and I believe are reflective of the way EDM culture has become increasingly mainstream during the past decade. The festivals are perhaps representative of broader cultural shifts in audience engagements with popular music. In a world of iTunes and iPods, instant access to a huge range of individual tracks (as opposed to albums) has become the norm. Festivals similarly provide their audiences with a "pick 'n' mix" selection. With their multiple stages, venues or arenas, with day-long line-ups, festivals provide a variety of music that is simply not available at a club night. Their success has taken the music to a wider audience, while at the same time providing this audience with a more professionally organised scene and ultimately contributing to the continued existence of EDM culture in Sydney. 


\section{NOTES}

1 While "EDM" includes a variety of different styles and scenes, I use it in this article in reference to "commercial" dance music and club culture specifically in the city of Sydney, and to describe festivals that feature DJs of house, trance, electro, techno and breaks all on the same line-up. In using the term "commercial", I am referring to club nights, festivals and events that are promoted through extensive advertising and staged with the primary goal of profit margins. By contrast, events in Sydney's alternative EDM scenes are less visible to the general public and are motivated by a variety of causes other than self-promotion and financial success.

2 JackT, "Clubs Special, Part Three: The festival effect", 21 May 2010, <http://www.inthemix. com.au/features/46835/Clubs Special Part Three The festival effect> (accessed 21 May 2010).

3 See Fikentscher (2000) for a discussion of the impact AIDS had on the underground dance scene in New York during the 1980s.

4 Luckman notes that the Hordern is "a large barn-like venue located within the agricultural showgrounds, not far from the city's CBD” (2002: 48). It most typically now acts as a venue for rock concerts, while some dance festivals (We Love Sounds, Space) are held there and in surrounding venues. The area is now part of the Fox Studios Entertainment Quarter.

5 Goodwill, interview with the author (Sydney), 8 September 2004.

6 Goodwill, interview with the author (Sydney), 8 September 2004.

7 Trent Rackus, interview with the author (Sydney), 27 September 2004.

8 John Wall, interview with the author (Sydney), 16 September 2005.

9 JackT, “We Love Sounds Perth cancelled”, 26 May 2010, < http://www.inthemix.com.au/news/ aust/46909/We_Love_Sounds_Perth_cancelled $>$ (accessed 26 May 2010).

10 John Wall, interview with the author (Sydney), 16 September 2005.

11 JackT, "What's an international worth?", 22 September 2010, < http://www.inthemix.com.au/ features/48103/Whats_an_international_worth> (accessed 22 September 2010).

12 daverh, "Harbourlife Gold Coast gets 'postponed', 27 October 2010, <http://www.inthemix. com.au/news/aust/48417/Harbourlife Gold Coast gets_postponed $>$ (accessed 27 October 2010).

$13<$ http://www.fuzzy.com.au $>$

14 <http://www.themusicnetwork.com/music-features/industry/2010/06/14/the-hot-seatfuzzys-john-wall> (accessed 14 June 2010).

15 Swales, Kris. 2010. “Jonathan Wall: Icon”. 3D World. 15 June: 26-7.3D World is a free weekly street-press publication that focuses on EDM culture.

16 John Wall, interview with the author (Sydney), 16 September 2005.

17 <http://www.inthemix.com.au $>$ is a website dedicated to dance music culture in Australia, which features news, reviews, forums, photo galleries, online ticket sales and club listings, and with each state capital city within Australia (Adelaide, Brisbane, Canberra, Melbourne, Perth and Sydney) receiving focus, so that the site caters specifically for the scenes at the local urban level as well as the national level. Since its inception in 2000 by Andre Lackmann, Neil Ackland and Libby Clark, the site has grown from a small platform for news and photographs 
to a company (Sound Alliance: see <http://www.thesoundalliance.net $>$ ) with other websites (such as the rock-based <http://www.fasterlouder.com.au $>$ ), an associated record label, touring division and radio station. With its recent tenth anniversary, ITM underwent a complete redesign.

18 JackT, "Clubs Special, Part One: The state of clubs in 2010", 19 May 2010, <http://www. inthemix.com.au/features/46833/Clubs Special Part One The state of clubs in 2010> (accessed 19 May 2010).

19 JackT, "Clubs Special, Part Five: The forecast for the future", 23 May 2010, <http://www. inthemix.com.au/features/46837/Clubs Special Part Five The forecast for the future $>$ (accessed 23 May 2010).

20 JackT, "Clubs Special, Part Two: What has become of weekly clubbing", 20 May 2010, < http:// www.inthemix.com.au/features/46834/Clubs Special Part Two What has become of weekly_clubbing $>$ (accessed 20 May 2010).

21 < http://www.djmag.com/top100clubs/?op=detail\&start=\&page=7\&year=2009\&id=167> (accessed 6 December 2010).

22 JackT, “Turning 10 with inthemix: We Love Sounds”, 10 May 2010, <http://www.inthemix. com.au/features/46725/Turning_10 with_inthemix_We_Love_Sounds $>$ (accessed 10 May 2010).

23 JackT, “We Love Sounds goes into liquidation”, 28 October 2010, < http://www.inthemix.com. au/news/aust/48434/We Love Sounds goes into liquidation $>$ (accessed 28 October 2010).

24 <http://www.themusicnetwork.com/music-features/industry/2010/10/06/festival-overloadhave-we-reached-critical-mass $>$ (accessed 6 October 2010$)$ and $<$ http://www.themusicnetwork. com/music-news/industry/2010/12/15/2010-the-year-in-music-news/> (accessed 15 December 2010).

$25<$ http://www.themusicnetwork.com/music-features/industry/2010/06/14/the-hot-seatfuzzys-john-wall > (accessed 14 June 2010).

26 JackT, “What's an international worth?”, 22 September 2010, < http://www.inthemix.com.au/ features/48103/Whats an international worth $>$ (accessed 22 September 2010). 


\section{REFERENCES}

Bidder, Sean. 2001. Pump Up The Volume: A History of House. London: Channel 4 Books.

Brewster, Bill and Frank Broughton. 2000. Last Night a DJ Saved My Life: The History of the Disc Jockey. London: Headline.

Collin, Matthew. 1998. Altered State: The Story of Ecstasy Culture and Acid House. 2nd ed. London: Serpent's Tail.

Connell, John and Chris Gibson. 2003. Sound Tracks: Popular Music, Identity and Place. London: Routledge.

Fikentscher, Kai. 2000. "You Better Work!" Underground Dance Music in New York City. Hanover: University Press of New England.

Gibson, Chris and Rebecca Pagan. 2000. "Rave Culture in Sydney, Australia: Mapping Youth Spaces in Media Discourse”. < http://www.snarl.org/youth/chrispagan2.pdf> (accessed 15 August 2003).

Gilbert, Jeremy and Ewan Pearson. 1999. Discographies: Dance Music, Culture and the Politics of Sound. London: Routledge.

Harley, Ross and Andrew Murphie. 2007. "Australian Electronica: A Brief History". In Sounds of Then, Sounds Of Now: Popular Music in Australia, ed. Shane Homan and Tony Mitchell, 93-113. Hobart: ACYS.

Haslam, Dave. 2001. Adventures on the Wheels of Steel: The Rise of the Superstar DJs. London: Fourth Estate.

Luckman, Susan. 2002. "Party People: Mapping Contemporary Dance Music Cultures in Australia”. Ph.D. Dissertation, University of Queensland, Brisbane.

Murphie, Andrew and Edward Scheer. 1992. "Dance Parties: Capital, Culture and Simulation". In From Pop to Punk to Postmodernism, ed. Philip Hayward, 172-84. Sydney: Allen \& Unwin.

Negus, Keith. 1996. Popular Music in Theory: An Introduction. Cambridge: Polity.

Phillips, Dom. 2009. Superstar DJs: Here We Go! London: Ebury Press.

Poschardt, Ulf. 1998. DJ Culture. London: Quartet Books.

Reynolds, Simon. 1999. Generation Ecstasy: Into the World of Techno and Rave Culture. New York: Routledge.

Shuker, Roy. 2002. Popular Music: The Key Concepts. London: Routledge.

St John, Graham. 2009. Technomad: Global Raving Countercultures. London: Equinox.

Thornton, Sarah. 1995. Club Cultures: Music, Media and Subcultural Capital. Cambridge: Polity.

FILMOGRAPHY

Hindmarch, Carl. 2001. Pump Up The Volume. UK: Channel 4. 